\title{
WOOD ANEMONE. ANEMONE NEMOROSA L. ANALYTICAL REVIEW
}

\author{
(C) A. Lukianchuk, O. Khropot, Y. Konechnyi, R. Konechna, V. Novikov
}

Проаналізовано літературні джерела та узагальнено дані щңодо ареалу, вмісту біологічно активних сполук та спектру використання у фармації та медицині Апетопе петогоsа.

Aneтопе петоrosa - багаторічна трав'яниста рослина з родини жовтецевих (Ranипсиlaceaе). Рослина неофіцинальна, широко застосовується народною медициною як протипухлинний, протизапальний, спазмолітичний, седативний, потогінний, бактерицидний, протимікробний, протигрибковий, відхаркувальний, діуретичний засіб. Основними біологічно активними речовинами Апетопе петогоsа є: алкалоїди, глікозиди (протоанемонін, анемонін, ранункулін, деякі типи сапонінів, таніни), вітамін С, смоли, органічні кислоти (хелідонова кислота), кумарини, флавоноїди та ү-ліноленова кислота.

Рослину відносять до регіонально рідкісних рослин адміністративних територій України, тому зважаючи на результати проведених фітохімічних та фармакологічних досліджень стає зрозумілим, щяо подальше використання Апетопе петогоsа, як лікарської рослинної сировини є актуальним завданням фармації та фармацевтичної біотехнології з огляду на перспективність наукових досліджень щзодо створення нових фітозасобів.

Враховуючи значний досвід застосування в народній медицині, широкий спектр фармакологічної активності, вміст цінних біологічно активних сполук Аnетопе петогоsа є перспективною та цінною сировиною для одержання та виробництва фітохімічних препаратів та впровадження їх у практичне застосування

Ключові слова: Ranunculaceae, Anетопе nетоrosa, протоанемонін, біологічно активні речовини, фармакологічна дія

\section{Introduction}

Expanding the range of drugs, in particular, herbal remedies, is among the priorities of modern pharmacy. Members of buttercup family (Ranunculaceae) are promising objects for the study, as a source of biologically active compounds that have long been used in traditional medicine as drugs with diversified pharmacological action.

\section{Formulation of goals (tasks) of Article}

The aim of research was to analyze and summarize the literature data concerning the range, chemical composition of Anemone nemorosa herb and the prospects of the use for the further pharmacognostic, phytochemical and pharmacological studies.

3. Statement of the basic material of the study (methods and objects) with the justification of the results

Literature and electronic information sources regarding range, chemical composition and pharmacological activity of Anemone nemorosa herb were chosen.

Common Ukrainian names: vesnukha, white vesnukha, scilla-vesnukha, little scilla-vesnukha, spring scilla, kozen'ka, kolopel'ka, white kolopel'ka, kuroslip, pereliska, snowdrop, snowdrops, white scilla, pryliska, Corydalis (Huzulschyna), white Corydalis, cuckoo's Corydalis, bullfinch, Snow-maiden, spring yahlychka, koroliska, spring yaslychka, snowflake, ambrika. According to Melnyk: snowdrop konopelka; according to Shavel: white snowdrop; according to Qualifier of 1965 : Anemone nemorosa.

The name cames from the Greek anemos - wind, nemorosa - the one that grows in oak.
Russian name: Anemone nemorosa [1].

English names: WindFlower, Wood Anemone, WindCrowfoot, SmellFox, Thimbleweed.

There are several myths about the origin of the name Anemone nemorosa. One myth says that Venus loved Adonis, and when the god Ares in the guise of a bull struck Adonis, Anemone nemorosa grew where Venus tears fell to the ground, while she was mourned her dead lover. The other less known myth says that Anemone was the favorite nymph of Zephyr west wind. Flora the goddess of flowers, was jealous that Zephyr liked Anemones, so she transformed the nymph into a flower. When Zephyr learned about Anemone's transformation, he left at the mercy of cruel northern wind Boreas, whose coldness and cruelty caused that Anemone quickly wilted. This myth is very similar to the German legend in which beautiful Zephyr, the god who brought life into all plants, loved Anemone. Chloris became jealous of Anemones and took her away from her house. Cowardly Zephyr left Anemone and turned her into a flower. By Victorian flowers language, Anemone represents poor health, connection with disease and death that transcends the culture. For example, in Chinese culture, Anemone is synonymous with death, and in ancient Rome Anemones used in garlands for the dead. Romans used Anemones to decorate ceremonial altars, especially dedicated to Venus. In some parts of Europe, Anemone symbols meets associations with immortality and Easter. Due to this, Anemone is known as the rebirth flower. Christian mythology of Anemone combined with the form of three petals of the flower led to the fact, that it is known as Trinity herb. Anemone is also in pagan folklore. For example, in 
British tales fairies use Anemone nemorosa as a shelter against rain [2].

Botanical description. Anemone nemorosa (Fig. 1) is a herbaceous perennial plant of the buttercup (Ranunculaceae) family. Stem is erect, $10-25 \mathrm{~cm}$, with welldeveloped rhizome. Leaves mostly cauline collected by three in the ring. The flowers are medium size $-20-$ $30 \mathrm{~mm}$ in diameter, white, pale pink, sometimes purple with six to eight petals, closed and tend in bad weather and at night. Fruit - achene oblong, with short noses [3-5]. The herb is ephemeride, blooms in April and May. Propagated by seeds and rhizomes. Flowers occur only 10-12 years after sowing the seeds [1].

If in spring rhizome remains without aerial part, the herb dies. This is the reason why the plant is included into the lists of regionally rare plants of administrative territories of Ukraine in Dnipropetrovsk, Lugansk, Sumy and Chernihiv regions [6].

Anemone nemorosa grows in deciduous forests, forest edges, clearings in West Polesie area and Foreststeppe zone (Fig. 2). In medicine herb collected during flowering period is used.

The plant is non-officinal [3].

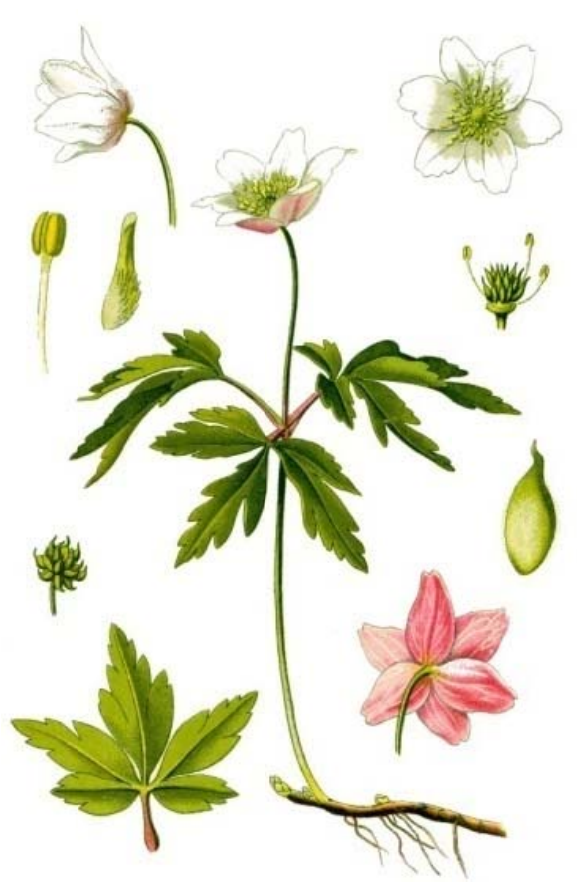

Fig. 1. Anemone nemorosa L.

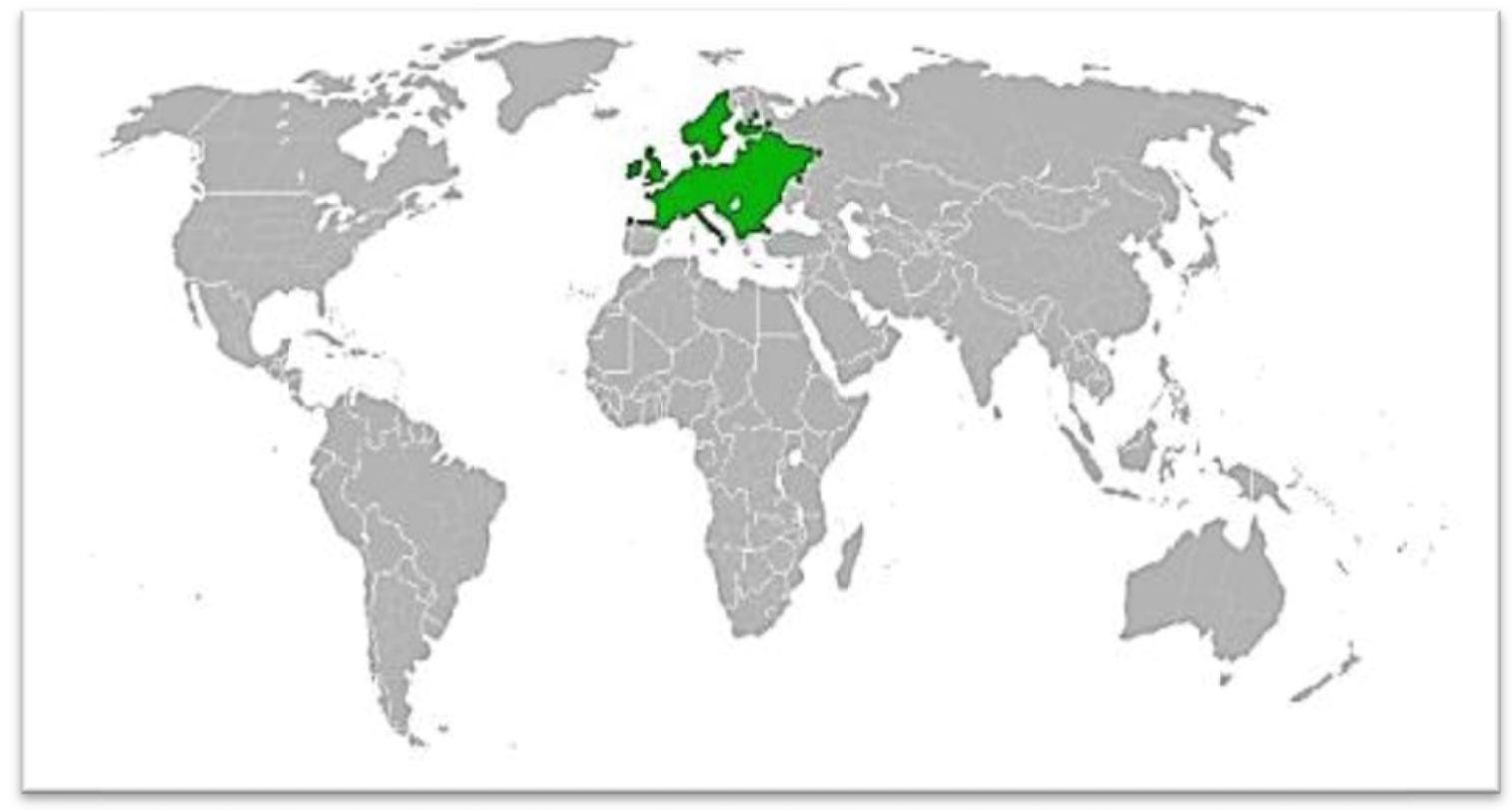

Fig. 2. Anemone nemorosa spread range

\section{History of use and research.}

There are a lot of facts pointing to the ancient use of Anemone nemorosa, for example, by such scientists and doctors as Culpepper (1720), Motherby (1775), Meyrick (1799), Porcher (1849), Clapp (1850). In 1804, Anemone nemorosa was included to Edinburgh Pharmacopoeia as one from the "List of substances included in some of the latest and most respected Pharmacopoeias, but not included in some British colleges (corporations) Pharmacognosy (Pharmacopoeias)", and in 1803 it was officinal herb in Russia, in 1817 - in Sweden, in 1833 in Torino; the herb was included to the first (1833) and the second (1834) editions of the U.S. Pharmacopoeia, belonged to the "Pharmacopoea Homoeopathica Poly- glottica" (1872). Hooper included it to the first edition of his Medical Dictionary (1817) [7].

Different biological aspects of Anemone nemorosa were studied, including population biology (Ernst, 1983), the rhizome growth and cultivation possibility (Shirreffs and Bell, 1984), spreading in nature (Piroznikov, 1994), growth dynamics (Cowie et al. 1995), ecosystems (Erikson, 1995; Holderegger, 1996), the importance of gender and vegetative reproduction (Holderegger et al., 1998), genetic structure (Stehliki Holderegger, 2000) and resistance to drying out during embryo development (Ali et al., 2007 ) [8].

Chemical composition. Anemone nemorosa herb contains: alkaloids, glycosides (Protoanemonin, Anemo- 
nin, Ranunculine, some types of saponins, tannins), vitamin C, resins, organic acids (chelidonic acid (Fig. 3)), coumarins, flavonoids, etc. [1,9]. Besides, $\gamma$-linolenic acid was found in seed oil.

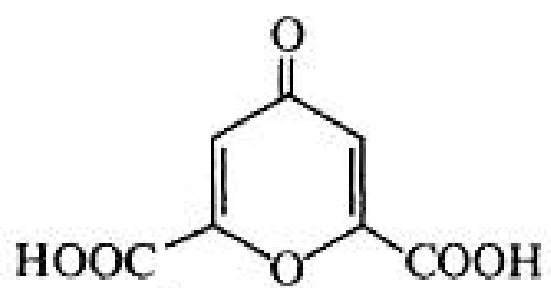

Fig. 3. Chelidonic acid

The main active substance of Anemone nemorosa is Protoanemonin. It is viscous colorless oily liquid with a pungent odor. Frohnei Pfander described Protoanemonin as volatile, oily and poisonous substance, which is very similar to mercaptans [11]. It has antimicrobial and fungistatic, antimutagenic $[12,13]$, sedative effect, it is active against gram-positive and acid-resistant bacteria, also it tones up the nervous system, activates the reticuloendothelial system and improves endopoez. Scientists by using transcriptomics and proteomics found that Protoanemonin significantly reduces gene expression and proteins secretion, which are known to be under the control by quorum sensing in Pseudomonas aeruginosa [14]. Moreover, they found genes activation and gene products involved in the iron deficiency reaction. Thus, the quorum sensing inhibition, as a product of antibiotics, probably is a phenomenon found in bacterial groups' complex [14].

studies of Anemonin concluded that Anemonin mechanism of action can significantly prevent diarrhea, which is caused by polycythemia vera and E.coli, probably can influence on the regulation of EGFR epidermal growth factor and TGF $\beta 1$ transforming growth factor beta [17].

The researchers point out that Anemonin inhibits cell activity against tyrosinase and affects the protein and mRNA levels in human melanocytes inhibiting melanin synthesis. Therefore, Anemonin can be used for cosmetic hypopigmentation [18]. Anemonin is able to inhibit the Nitrogen oxide (NO) synthesis by modulation of the expression of iNOS (inducible Nitrogen oxide synthase) $[19,20]$. This may explain its antiinflammatory effect [20, 21].

It is also known that Anemonin inhibits endothelin-1 (ET-1) and the Inter-Cellular Adhesion Molecule 1 (ICAM-1) in RIMEC (rats intestinal microvascular endothelial cells), preventing intestinal microvascular dysfunction. It is assumed that Anemonin can be used to treat cardiovascular system diseases, arthritis, and others, when ET-1 and NO are involved in the pathogenesis intermediation [20].

Scientists have found that previous Anemonin therapy substantially restored levels of certain biochemical parameters, reduced cerebral infarct size and improved neurological scar in ischemic animals. In addition, Anemonin spreading in blood plasma and brain tissues, as well as brain-plasma distribution coefficient, which is 0.7 after 90 minutes, show that this compound can penetrate the blood-brain barrier. These results show that the previous Anemonin therapy provides a significant protection against brain ischemia reperfusion in rats due to, at least partially, antioxidant properties and apoptosis inhibition. Antioxidant and antiapoptosis properties of Anemonin have neuroprotective potential in ischemic brain [22].

Pharmacological studies in pigs have shown that Anemonin reduces the expression of TNF-a, IL-6, IL-8 and IL-1b mRNA. Besides, Anemonin also caused TGF-b1 mRNA and proteins

Fig. 4. The scheme of transformation of Protoanemonin into Anemonin

During the drying of the herb, Protoanemonin is converted into Anemonin (Fig. 4), a white crystalline powder, poorly soluble in water and well soluble in organic solvents (Fig. 5).

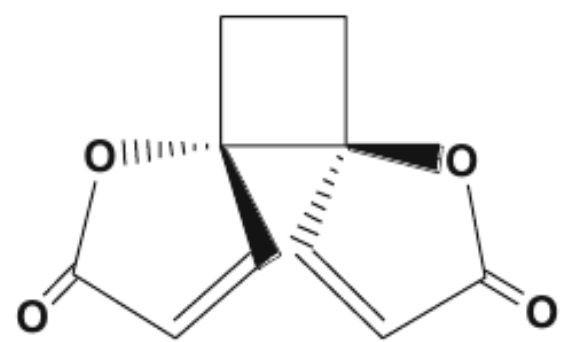

Fig. 5. Anemonin structure

It has a pronounced analgesic and antispasmodic [15], fungicidal (but less than Protoanemonin) [16], sedative effect. Anemonin is also used in asthma, whooping cough, rachitis, and uterine bleeding. Scientists in their expression, expression of Smad4 and Smad7 m-RNA, as well as epidermal growth factor and receptors of epidermal growth factor (EGFR) mRNA in small intestine mucosa. It can be assumed that Anemonin soothes LPS-induced intestinal injury by improving the mucosa recovery, relieves intestinal inflammation and the effect of TGF-b1 canonical Smads and EGFR signaling pathway [23].

Pharmacological effect of Anemone nemorosa is highly comprehensive. The herb is used internally as an antitumor, analgesic (e.g. for stomach ache, headaches, radiculitis), anti-inflammatory (at inflammation of lungs, kidneys, spleen, eyes, malignant ulcers) [3, 4], antispasmodic, sedative, diaphoretic, bactericidal, antimicrobial, antifungal, expectorant, diuretic, and abortive agent [24, 25].

The use in traditional medicine. Anemone nemorosa is used as a decoction for treatment of malignant tumors, heart diseases, pneumonia, fever, stomach ache, as abortive agent [3]. Also, it is used in the form of infusions, tinctures, decoctions of herb for treatment of heart diseases, apathy, fever, shortness of breath, asthma, gallstones, sexual weakness of men and women, menstrual 
disorders, three-day fever, rheumatic gout, scabies, leprosy, shingles, whooping cough, paralysis, syphilis, gout, dropsy, and it increases kidneys and lungs activity. Anemone nemorosa is often used in herbal teas in complex with other herbs, which are often prescribed for treatment of shortness of breath, the psychical and emotional instability, scabies [4, 24].

The herb is used externally for treatment of rheumatism, gout, skin diseases, as an antiseptic, its juice is used against warts.

In homeopathy, Anemone nemorosa is used as a sedative, diuretic and diaphoretic agent [3].

Dosage forms. Infusion of Anemone nemorosa leaves: add $200 \mathrm{ml}$ of boiling water to 1 teaspoon of herb and leave for 30 minutes, drain, rub on $10 \mathrm{ml}$ into the skin of painful places 1 time per day. There is an overdose danger. After application wash hands carefully with soap [25].

Cold infusion: add $250 \mathrm{ml}$ of cool boiled water to 2 teaspoons crushed dried Anemones herb and leave for 20 hours, filter. Use 2 tablespoons 3 times per day. This infusion is also used for compresses (rheumatism, gout), lotions and washing (dermatitis, poor wound healing).
Tincture: 1 liter of alcohol, 100 grams of powdered Anemone nemorosa herb. Leave in a dark place and periodically shake. Filter after 7-10 days. It can be used both externally and internally.

Toxicity and contraindications. The herb is poisonous. Leaves have narcotic-like effect. They lose toxicity after drying.

Infusion of Anemone nemorosa should not be used by pregnant (abortive effect), during lactation, and is not recommended at kidneys inflammation. Since the plant is poisonous, to avoid poisoning the dosage should be followed and self-feeling should be monitored.

\section{Conclusion}

The proceed literature point to the wide spectrum of pharmacological activity, the content of valuable biologically active compounds and an ancient experience of use of Anemone nemorosa in tradition medicine. Considering the results of the carried out phytochemical and pharmacological studies, it becomes clear that the further use of Anemone nemorosa as a herbal material is relevant and promising issue in pharmacy.

\section{References}

1. Shavel, I. Tsilyushchi roslyny Ukrayiny [Text] / I. Shavel. - Lviv: BaK, 2012. - 432 p.

2. Christopher, C. Encyclopedia of Cultivated Plants: From Acacia to Zinnia 3 Vol.: From Acacia to Zinnia [Text] / C. Christopher. - Santa Barbara, 2013. - 1236 p.

3. Likars'ki roslyny: Entsyklopedychnyy dovidnyk [Tekst] / A. M. Hrodzins'kyy (Ed.). - Kyiv: Vydavnytstvo «Ukrayins'ka Entsyklopediya» im. M. P. Bazhana, 1992. - 544 p.

4. Likars'ki roslyny Karpat. Dykorosli ta kul'turni [Text] / O. Kozoriz (Ed.). - Uzhgorod: Mystets'ka Liniya, 2007. - 504 p.

5. Zemlynskyi, S. E. Lekarstvennye rasteniya SSSR [Text] / S. E. Zemlynskyi. - Moscow: Publishing house of the Moscow Society of Naturalists, $1952 .-507$ p.

6. Chervona knyha Ukrayiny [Electronic resource]. - 2010-2017. - Available at: http://redbook-ua.org/

7. Anemone (Wood) [Electronic resource]. - 1995-2017. - Available at: http://Botanical.com/

8. Mondoni, A. Habitat-correlated seed germination behaviour in populations of wood anemone (Anemone nemorosa L.) from northern Italy [Text] / A. Mondoni, R. Probert, G. Rossi, F. Hay, C. Bonomi // Seed Science Research. - 2008. - Vol. 18, Issue 4. - P. 213-222. doi: 10.1017/s0960258508084997

9. Hao, D.-C. Anemone medicinal plants: ethnopharmacology, phytochemistry and biology [Text] / D.-C. Hao, X. Gu, P. Xiao // Acta Pharmaceutica Sinica. - 2017. - Vol. 7, Issue 2. - P. 156-168. doi: 10.1016/j.apsb.2016.12.001

10. Tsevegsuren, N. 7-Linolenic Acid in Anemone spp. Seed Lipids [Text] / N. Tsevegsuren, K. Aitzetmuller // Institute for Chemistry and Physics of Lipids, Federal Center for Cereals, Potato and Lipid Research (BAGKF). - 1993. - Vol. 28, Issue 9. P. 841-846. doi: 10.1007/BF02536240

11. Frohne, D. Poisonous Plants: a handbook for doctors, pharmacists toxicologists, biologists and veterinarians [Text] / D. Frohne, H. J. Pfander. - London: Manson Publishing Inc., 2005. - 480 p.

12. Minakata, H. Protoanemonin, an antimutagen isolated from plants [Text] / H. Minakata, H. Komura, K. Nakanishi, T. Kada // Mutation Research/Genetic Toxicology. - 1983. - Vol. 116, Issue 3-4. - P. 317-322. doi: 10.1016/0165-1218(83)90069-1

13. Martin, M. L. In vitro activity of protoanemonin, an antifungal agent [Text] / M. L. Martin, L. Roman, A. Dominguez // Planta Medica. - 1990. - Vol. 56, Issue 1. - P. 66-69. doi: 10.1055/s-2006-960886

14. Bobadilla Fazzini, R. A. Protoanemonin: a natural quorum sensing inhibitor that selectively activates iron starvation response [Text] / R. A. Bobadilla Fazzini, M. E. Skindersoe, P. Bielecki, J. Puchalka, M. Givskov, V. A. P. Martins dos Santos // Environmental Microbiology. - 2012. - Vol. 15, Issue 1. - P. 111-120. doi: 10.1111/j.1462-2920.2012.02792.x

15. Roth, L. Poisonous plants-phytotoxins [Text] / L. Roth, M. Daunderer, K. Kormann. - Hamburg, 2006.

16. Misra, S. Antifungal principle of Ranunculus sceleratus [Text] / S. Misra, S. Dixit // Economic Botany. - 1980. - Vol. 34, Issue 4. - P. 362-367. doi: 10.1007/BF02858312

17. Maior, M. Natural compounds with important medical potential found in Helleborus sp [Text] / M. Maior, C. Dobrota // Open Life Sciences. - 2013. - Vol. 8, Issue 3. - P. 272-285. doi: 10.2478/s11535-013-0129-x

18. Huang, Y.-H. Anemonin is a natural bioactive compound that can regulate tyrosinase-related proteins and mRNA in human melanocytes [Text] / Y.-H. Huang, T.-H. Lee, K.-J. Chan, F.-L. Hsu, Y.-C. Wu, M.-H. Lee // Journal of Dermatological Science. - 2008. - Vol. 49, Issue 2. - P. 115-123. doi: 10.1016/j.jdermsci.2007.07.008

19. Hu, Y. Pulsatilla decoction and its active ingredients inhibit secretion of NO, ET-1, TNF-alpha, and IL-1 alpha in LPSinduced rat intestinal microvascular endothelial cells [Text] / Y. Hu, X. Chen, H. Duan, Y. L. Hu, X. Mu // Cell Biochemistry and Function. - 2009 - Vol. 27, Issue 5. - P. 284-288. doi: 10.1002/cbf.1570

20. Duan, H. Effect of anemonin on NO, ET-1 and ICAM-1 production in ratin testinal microvascular endothelial cells [Text] / H. Duan, Y. Zhang, J. Xu, J. Qiao, Z. Suo, G. Hu, X. Mu // Journal of Ethnopharmacology. - 2006. - Vol. 104, Issue 3. - 
P. 362-366. doi: 10.1016/j.jep.2005.09.034

21. Lee, T. H. Anemonin, from Clematis crassifolia, potent and selective inducible nitric oxide synthase inhibitor [Text] / T. H. Lee, N. K. Huang, T. C. Lai, A. T. Y. Yang, G. J. Wang // Journal of Ethnopharmacology. - 2008. - Vol. 116, Issue 3. P. 518-527. doi: 10.1016/j.jep.2007.12.019

22. Jia, D. Anemonin Alleviates Nerve Injury After Cerebral Ischemia and Reperfusion (I/R) in Rats by Improving Antioxidant Activities and Inhibiting Apoptosis Pathway [Text] / D. Jia, B. Han, S. Yang, J. Zhao // Journal of Molecular Neuroscience. 2014. - Vol. 53, Issue 2. - P. 271-279. doi: 10.1007/s12031-013-0217-z

23. Xiao, K. Anemonin improves intestinal barrier restoration and influences TGF-b1 and EGFR signaling pathways in LPSchallenged piglets [Text] / K. Xiao, S. T. Cao, L. F. Jiao, F. H. Lin, L. Wang, C. H. Hu // Innate Immunity. - 2016. - Vol. 22, Issue 5. - P. 344-352. doi: 10.1177/1753425916648223

24. Alteya likars'ka, anemona dibrovna, anemona lisova: opys roslyn [Electronic resources]. - 2012. - Available at: http://ru.osvita.ua/vnz/reports/biolog/27498/

25. Chekman, I. S. Klinichna fitoterapiya [Text] / I. S. Chekman. - Kyiv: Vydavnytstvo A. S. K., 2003. - 552 p.

Рекомендовано до публікаиії д-р фарм. наук Лесик Р. Б. Дата надходження рукопису 14.04.2017

Anna Lukianchuk, Department of Technology of Biologically Active Substances, Pharmacy and Biotechnology, Lviv Polytechnic National University, Bandera str., 12 Lviv, Ukraine, 79013

E-mail: myfancyyy@gmail.com

Oksana Khropot, Postgraduate student, Department of Technology of Biologically Active Substances, Pharmacy and Biotechnology, Lviv Polytechnic National University, Bandera str., 12 Lviv, Ukraine, 79013

E-mail: Lvov.mp@gmail.com

Yulian Konechnyi, Internship doctor, Department of Microbiology, Virology and Immunology, Lviv National Medical University named after Danylo Galician, Pekarska str., 69 Lviv, Ukraine, 79010

E-mail: docyulian@gmail.com

Konechna Roksolana, PhD, Assistant, Department of Technology of Biologically Active Substances, Pharmacy and Biotechnology, Lviv Polytechnic National University, Bandera str. 12., Lviv, Ukraine, 79013

E-mail: rkonechna@ukr.net

Novikov Volodymyr, ScD, Professor, Head of Department, Department of Technology of Biologically Active Substances, Pharmacy and Biotechnology, Lviv Polytechnic National University, Bandera str., 12 Lviv, Ukraine, 79013

E-mail: vnovikov@polynet.lviv.ua 